\title{
Karl Barth's epistemology: A critical appraisal
}

\author{
Daniël P Veldsman \\ Department of Dogmatics and Christian Ethics \\ University of Pretoria
}

\begin{abstract}
Can the great $20^{\text {th }}$ century systematic theologian Karl Barth justify the fundamental beliefs he holds regarding the priority of God's revelation in Jesus Christ as put forward in his impressive and comprehensive Kirchliche Dogmatik? Is it enough and thus theologically justifiable to simply state in the words of Barth that the best theology would need no advocates: it would prove itself? In my appraisal of Barth's epistemological stance, I would like to argue in this article that his stance in the first place, does not only lead to a total isolation of theological reflection, but secondly through his highly exclusive claim, takes on the character of a personal religious credo expanded into a comprehensive doctrine beyond any form of control, and ultimately thirdly, becomes methodologically in essence a specifically Barthian theology from below.
\end{abstract}

Wenn die Theologie sich eine Wissenschaft nennen lässt oder selber nennt, so kann sie damit keinerlei Verpflictung übernehmen, sich an den für andere Wissenschaften gültigen Massstäbem messen zu lassen.

(Karl Barth 1947:8)

\section{INTRODUCTION}

In my appraisal of Barth's theology, I am not questioning the worldwide influence and impact of his theological contribution to $20^{\text {th }}$ century Reformed theology. ${ }^{1}$ Its immense. Its geniality, its closely knitted and thorough thought through dogmatic system, its comprehensiveness, its persuasiveness, its

\footnotetext{
${ }^{1}$ To view the vast corpus of literature on Barth, see the bibliography compiled by HansMarkus Wildi (1997) which covers the period up to 1992. For literature after 1992, see the online bibliography at http//library.ptsem.edu/collections/barth which is jointly co-hosted by Princeton Theological Seminary, Princeton, USA, The Theological University of the Protestant Church of the Netherlands, Netherlands, and the Ruhr-Universität, Bochum, Germany.
} 
depth, its sheer beauty as evangelical theological - just think for one moment of his exposition of the love and grace of God (see e $\mathrm{g}$ his exposition of "Gottes Sein als der Liebende in der Freiheit" in his Kirchliche Dogmatik II/1) is in my opinion incontestable (see e g Mueller 1972:13, 140-150; Torrance 1962:15, 201ff; Torrance1990:x-xi,1; Webster 2000a:1, 164-175; Webster $2000 b: i x)$. It has to be - in my opinion - compulsory reading for every new student to the field of theological reflection. Interestingly, this was also the view point of almost $80 \%$ of my students (when I was still teaching at the University of South Africa, Pretoria) who were doing our systematictheological module "Reflections on faith". Their first assignment was on faith as gift. They had to choose between the theological approaches to "faith as gift" by either Barth or Pannenberg. Almost $80 \%$ of the students chose to discuss Barth's approach with the strongest of approval and appreciation. The reason most probably being - in my opinion - the strong existential-spiritual appeal that invitingly and assuredly flows from his theological approach. ${ }^{2}$

But this red pastor of Safenwil - a small industrial town with its 16000 occupants, located in the canton of Aargau in central Switzerland - where he wrote his Römerbrief (1918) - has not only left us with thirteen volumes of his magnus opus, his Kirchliche Dogmatik (1932-1968), but has left us with a depth and width of theological reflection on which we can ponder on for the rest of our academic lives (cf Busch 1978; Busch 1997; Webster 2000a:1316). Torrance (1990:x-xi) can therefore rightly state: "Whether or not contemporary theology agrees with Barth, it cannot escape the questions he has raised, or avoid dealing with the situation he has created. If theological advance is to be made, it will not be by passing him or going round him, but only by going through and beyond him ...."

Indeed. He has left us with - not only a depth, and a width of reflection - but also a height. In my playful formulation in reference to height, I want to turn my focus to his methodological approach traditionally called "an approach from above". Why is it designated as "an approach from above"? What does it entail? Why do I focus on it? I focus on it since there are serious questions that have to be put to Barth regarding his methodological approach "from above". Serious questions, since his approach has devastating implication for the integrity of theological reflection, and specifically, for the acknowledgment

\footnotetext{
${ }^{2}$ To find one's way the first time round through the vast corpus of literature on Barth, is not that easy. Perhaps it can be helpful to suggest the following books for introductory reading: (1) Hans Urs von Balthasar (1951), Karl Barth: Darstellung und Deutung seiner Theologie. It has been translated in 1972 as: The Theology of Karl Barth. (2) Thomas F Torrance (1962), Karl Barth: An Introduction to his early Theology. (3) G C Berkouwer (1956), The Triumph of Grace in the Theology of Karl Barth. (4) Eberhard Busch (1998), Die grosse Leidenschaft: Einführung in die Theologie Karl Barths. It has been translated in 2004 as: The great passion: An introduction to Karl Barth's Theology. (5) John Webster (2000), Barth.
} 
of theology as a science. ${ }^{3}$ To put it differently: Barth's epistemological stance is very questionable and problematic. It almost boils down - if one wants to summarise his position - to an insensitive formulation such as: One must first believe in Barth, and then one can believe in God. ${ }^{4}$ Can I however substantiate this alarming remark? To substantiate my remark, I am firstly going to give a brief indication of his historical context, secondly of his basic theological structure and thirdly, of the problematic implications of his approach. But before I turn to these three points, I would like to give a short definition of my understanding of epistemology.

Epistemology - or also described as the theory of knowledge - refers to a branch of philosophy that studies the nature and scope of knowledge (cf Flew 1979:101-2). The word "epistemology" comes from the two Greek words "episteme" - that is, "knowledge" and "logos", that is, "explanation/words about/talking about" - that is, explaining knowledge/to talk about knowledge. To formulate it in a question: Do you really know what you think you know? And if, how do you know what you know? In a more pertinent formulation: On what grounds can you claim to know a particular fact. This is the question of justification. Justification for the beliefs we hold, and the reason(s) why we hold them. And it find expression in what is then technically (that is, in the context of the philosophy of science) labelled: a model of rationality. The critical question that I am going to put to Barth's theological approach - that is, to his underlying epistemological stance, or (implicit) model of rationality - will be: Dear Barth, Is it enough to simply state that the best theology would need no advocates: it would prove itself, and therefore it has no responsibility whatsoever regarding the other sciences (cf Barth 1947:1-10)? What about the implications of such a model of rationality? But let us now firstly turn to his historical context.

\section{BARTH IN CONTEXT}

Born in 1886 in Basel, Switzerland, the son of a professor of New Testament at Bern, his theological education exposed him to the views of theologians such as Von Harnack, Kierkegaard, Overbeck, Herrmann - also the

\footnotetext{
${ }^{3}$ The questions that I pose here are taking up as task the critical drift of the concluding section of Mueller's (1972:150-55) book on Barth. In the section entitled "Some critical questions" it is stated that - in the light of Barth's methodological approach - the question should be asked whether Barth can not rightly be accused of "metaphysical speculation" (151) and also for failing to relate Christian faith and theology to the questions and issues posed by the rising secular and scientific world view (154).

${ }^{4}$ Although formulated differently, Moltmann (1966:149) poses the same critical epistemological question regarding Barth's theological position: "Wer bürgt für die Wahrheit der Verkündigung und die Wahrhaftigkeit der Verkünder? ... An welcher Wirklichkeit beweisen die Worte ihre Wahrheit oder welche Wirklichkeit beweist die Wahrheit dieser Worte?"
} 


\section{Karl Barth's epistemology: A critical appraisal}

philosophy of Hegel and so I can continue - his appreciation of Anselm et cetera - just to mention a few (cf Busch 1978; Busch 1997; Busch 2004;

Mueller 1972:14ff; Torrance 1990:2ff, 27ff; Webster 2000a:2ff)! Especially the German systematic theologian Wilhelm Herrmann (cf Webster 2000a:3) is of great importance in my opinion - because next to Barth in Herrmann's lecture hall, sat another important theological scholar in the making: Rudolf Bultmann. Both of them came under the influence in the early 1920's of most probably one of the most undervalued German systematic theological teachers of that time - a teacher who lectured with such convincing passion that students were actually converted during his lectures! In an earlier article on the spirituality of Barth and Bultmann, I have argued that both of them have taken over the "Herrmann-spirituality" (characterised by the "inner life of Jesus" which we re-enact in our lives here and now) although they have respectively moulded it in different ways and in different directions - Bultmann, taking the historical route, turned it into "kerygma", Barth, taking the heavenly route, turned it into "revelation, senkrecht von oben" (Veldsman 1996; Veldsman 1997).

But Barth also turned his theological interest to the works of Schleiermacher - who became his life-long theological discussion adversary (cf Busch 2004:60, 187ff; Hunsinger 1991:121; Webster 2000a:14). However, his initial interests turned into opposition as he increasingly questioned the value of liberal theology in the wake of the tragedy of World War I. Through the preaching of the Moravian pastor Christoph Blumhardt and his study of the book of Romans, Barth became convinced while pastoring that the key to vital preaching, theology and the Christian life was the revelation of God in Christ and his resurrection. After accepting his first teaching post at Göttingen, Barth taught at Münster and then Bonn. He was then expelled by the National Socialists in 1935 for refusing to pledge allegiance to Adolf Hitler. Barth believed that his teachers had been misled by a theology which tied God too closely to the finest, deepest expression and experiences of cultured human beings, into claiming divine support for a war which they believed was waged in support of that culture, the initial experience of which appeared to increase people's love of and commitment to that culture. ${ }^{5}$ God - according to Barth has been domesticated! His protest found expression amongst others in the writing of the Barmen Declaration (1934). Subsequently he was then expelled by the National Socialists in 1935 for refusing to pledge allegiance to Adolf Hitler. He returned to Switzerland - taught at the University of Basel where he died in 1968.

\footnotetext{
${ }^{5}$ See in this regard the short but interesting article on Karl Barth in Wikipedia at http://en.wikipedia.org.wiki/Karl_Barth.
} 


\section{BASIC THEOLOGICAL STRUCTURE}

The prime leitmotiv of his theology is his insistence on the priority of God's revelation in Jesus Christ (cf Barth 1947:2-3). This leitmotiv may be seen methodologically as largely a reaction to the collapse of attempts by nineteenth-century liberal theology to ground Christian faith on some form of knowledge of the historical Christ (see his Die protestantische Theologie im 19. Jahrhundert which was published in 1946). In reaction, Barth ([1952] 1946) insisted on the priority of God's revelation in Jesus Christ. ${ }^{6}$ These revelatory events - his life, death and resurrection - were held to be the only avenue to a belief in God, since history as such could provide no basis for faith. By this means Barth also sought to stress the infinite qualitative distinction between God and humans - God as the "Ganz Andere". The fact that a human being can never - even with the most exact historical methods succeed in testing or even justifying God's truth became the most basic premiss of his reaction to any form of so-called natural theology (cf Busch 2004:24ff, 67ff; Mueller 1972:85ff; Schwöbel 2000:22ff; Torrance 1990:136ff; Van Huyssteen 1989:15). Ordinary history, he maintains, can in no way contain God's revelation so as to enable sinful humanity to approach or assess it rationally (Hart 2000:40). It is precisely on this basic premiss that the theological roads of Barth and his famous pupil Wolfhart Pannenberg (see e $\mathrm{g}$ his article Heilsgeschehen und Geschichte which was published in 1959 and re-published as part of his Grundfragen Systematischer Theologie in 1967) diverted. On the contrary, argues Barth, revelation is an incidental experience in which humanity is confronted vertically from above ("senkrecht von oben") with God's overwhelming presence (cf Hart 2000:47; Van Huyssteen 1989:15). By this means Barth wanted to transcend the crucial problems of nineteenth-century theology, namely historical relativism, and psychological subjectivism, by finding a new and rediscovered focal point in the absolute priority of God's revelation in Jesus Christ (Klooster 1977:36; Mueller 1972:33ff, 51ff; Torrance 1990:176). This he has done persuasively, but the price he was prepared to pay for this attempt was the total severing of the kerygma on the fate of Christ (as Geschichte) from ordinary history (as Historie). Thus too, the gospel/kerygma on Jesus Christ would become inaccessible to any form of positivistically structured attempts at historical reconstruction (contra historical relativism). A further implication was that a human, as a finite being, could never independently - bypassing God's revelation - and rationally conclude to the transcendence of God (cf Busch 2004:74ff; Hart 2000:42; Van Huyssteen 1989:15). Thus: humans could not

\footnotetext{
${ }^{6}$ Barth's insistence on the priority of Jesus Christ in the unfolding of his theological approach led to a chorus of criticism, charging him with christomonism or an illegitimate christocentrism (see eg Mueller 1972:151-2).
} 
on their own gain access to God in his transcendence (contra psychological subjectivism). ${ }^{7}$ And the implication of such a stance? That there is no direct and lasting revelation of God in history - neither scriptural nor a general revelation.

What then is the core of Barth's methodological approach "from above"? Or to put more in line with my epistemological focus: What kind of rationality model emerges from this mode of theologising? It is: Theological reflection is authentic only if and to the extent that it is a theology of revelation that finds its object in God, who in his omnipotent revelation, is in fact the Subject of theology. Or in Barth's (1928:276) own words: "Ausser dem Weg von oben nach unten gibt es hier überhaupt kein Weg". And: "Offenbarungswahrheit ist der frei handelnde Gott selber und ganz allein" (Barth 1947:15).

Theology for Barth was thus only possible as a science - a science of God and his revelation - but then in a strictly qualified manner: God and his Word becomes the only possible fount of theological thought (cf Barth 1947:2ff). True theology is possible only from above, from God's revelation down to humans, who receive that revelation in concrete obedience. Barth did not see this direct origin of theology in God's revelation as a product, or Setzung, of the human mind, since that revelation impacts on our reality with such authority that it establishes itself as the great Gegenüber, or counterforce, to our minds (cf Hart 2000:37ff; Van Huyssteen 1989:16). Barth sought to found his theology of revelation on an impressive choice for revelation rather than experience, theology rather than non-theological sciences, kerygmatic authority rather than rational argument. The scientific status of theological reflection was thus never a vital question for theology according to Barth, since theology is a function of the church which, in obedient faith, serves the gospel through critical guidance (cf Van Huyssteen 1989:16). Therefore Barth (1947:5) could emphatically state regarding the scientific status of theology: "Diese Frage ist auf keinen Fall eine Lebensfrage für die Theologie". And: "Eine wissenschaftstheoretische Begründung dafür lässt sich nich geben".

If Barth did speak about the scientific nature of theology, because he also wanted theological reflection to be relevant and to the point, it was then a relevance that was determined by the question whether theology interprets the Word of God in obedient faith. Relevance - as a commitment to God's revelation - was for Barth the prime criterion for scientific validity in theology not the methodological and cognitive issues. The uniqueness of theology needs no scientific, theoretical basis since the object of study (God and his revelation), and no presupposed concept of method and scientific validity,

\footnotetext{
${ }^{7}$ Barth's position on this point is aptly summarised by Hunsinger (1991:76) as follows: "... God is hidden from us absolutely. There is no way from us to God. We are separated from God by an ontological divide".
} 
guarantees responsible and correct progress in theology (cf Van Huyssteen 1989:17). In Barth's (1928:269) own words: God is the "in sich selbst begründeten Grund, der nun wirklich in keinem Sinn 'Objekt', sondern unaufhebbares Subjekt ist".

This implies: theological reflection is authentic only if and to the extent that it is a theology of revelation that finds its object in God, who, in his omnipotent revelation, is in fact the Subject of theology.

\section{PROBLEMATIC IMPLICATIONS OF BARTH'S EPISTEMOLOGICAL STANCE}

In my opinion, the sharpest and best critical formulation which questions Barth's model of rationality, comes very early in 1931 in the words of Heinrich Scholz (1931:27) in his article "Wie ist eine Evangelische Theologie als Wissenschaft möglich?", namely: "Aber die Energie des Glaubens, so hoch sie auch gefasst werden mag, ist natürlich im geringsten noch nicht ein Beweis für seine Legitimität."

In his introduction "Die Aufgabe der Dogmatik" to his Kirchliche Dogmatik, Barth $(1947: 7,17)$ indeed takes up the criticism that is directed against him by Scholz. Unfortunately he simply wipes Scholz's criticism (also that of Arthur Titus, see $p$ 8) from his theological table without addressing in detail the issues, and continued on his impressive self-chosen road of theological reflection in that volume and the subsequent 12 volumes! His selfchosen road however, can be criticised from an epistemological perspective (cf Van Huyssteen 1989:17-19), and on the following grounds:

- The total isolation of theological reflection. Since theology now takes it stand on a highly exclusive claim, it can no longer be integrated into the spectrum of non-theological sciences. Critical and meaningful dialogue with non-theological sciences is made impossible through the immunisation of theological reflection. In Barth's (1947:6) own words:

Die Existenz der andereren Wissenschaften, die höchst achtunggebietende Treue, mit der wenigstens manche von innen ihren Axiomen und Methoden nachgehen, kann und muss sie daran erinnern, dass auch sie ihrer eigenen Aufgabe ordentlich, d. h. mit entsprechender Treue nachgehen soll. Sie kann sich aber nicht von jenen darüber belehren lassen, was das in ihrem Fall konkret zu bedeuten hat. Sie hat methodisch nichts bei innen zu lernen.

- Over Barth's (theological) autonomous mental pursuit, hangs the unavoidable critical question: Did Barth succeed in finding the basis of 


\section{Karl Barth's epistemology: A critical appraisal}

a true theology in God and his revelation, or whether he found it in a subjective conception of God and his revelation.

Put differently: Does the rationality model used by Barth enable him to achieve the ideal of transcending historical relativism and psychological subjectivism. The answer is No. He remains caught - in a subtle theological sense - within the framework of precisely that kind of conceptual model. Barth's theology is rather a personal religious credo expanded into a comprehensive doctrine and thereby placed beyond any form of control or testing. He holds an unique conception of revelation which he constructed with great and impressive authority on a basis of personal belief, to serve as the only meaningful - in fact, the only correct and true foundation for theology. Thus the afore going alarming formulation can now be substantiated: You first have to belief in Barth, then in God. He thus fell prey to precisely that psychological subjectivism from which he sought to escape.

- Barth's revelationary theology as a so-called theology from above, is thus methodologically in essence a specifically Barthian theology from below, since the assumed authoritative premise of that theology as a conceptual construct, founded on a profound personal conviction, has ultimately been elevated into an authoritarian premise for a comprehensive program of thought.

- If I could then finally repeat my initial question to Barth, namely: Dear Barth, Is it enough to simply state that the best theology would need no advocates: it would prove itself, then the (hermeneutical) answer would be Nein - the price that is to be paid is (theologically) too high!

\section{CONCLUSION}

For us today as responsible theologians, we will have to pursue our theological reflection on God and revelation, as brought to us by the Bible, from a vantage point where we understand that "God" and "revelation" are accessible to us solely through an interpretative act (cf Van Huyssteen 1989:19). And in the construction of a valid theological model of thought for our time, the full hermeneutical implications of this fact would have to be faced by looking the world (of sciences) in the eyes! 


\section{Works consulted}

Barth, K 1928. Die dogmatische Prinzipienlehre bei Wilhelm Herrmann, in Die Theologie und die Kirche. Munich: EVZ-Verlag.

Barth, K 1947. Kirchliche Dogmatik 1/1. Zollikon-Zürich: Evangelischer Verlag.

Barth, K [1946] 1952. Die protestantische Theologie im 19. Jahrhundert. Zollikon: Evangelischer Verlag.

Busch, E 1978. Karl Barth aan die hand van zijn brieven en autobiografische teksten. Callenbach: Nijkerk

Busch, E 1997. Die Anfänge des Theologen Karl Barth in seinen Göttingen Jahren. Göttingen: Vandenhoeck \& Ruprecht.

Busch, E 2004. The great passion: An introduction to Karl Barth's theology. Michigan, MI: Eerdmans.

Flew, A 1979. s v "epistemology". Dictionary of philosophy. New York: St Martins's Press.

Hart, T 2000. Revelation, in Webster 2000b:37-56.

Hunsinger, G 1991. How to read Karl Barth: The shape of his theology. New York: Oxford University Press.

Klooster, F H 1977. Quests for the historical Jesus. Grand Rapids, MI: Baker Book House.

Moltmann, J 1966. Gottesoffenbarung und Wahrheitsfrage, in Busch, E, Fangmeier, J \& Geiger, M (Hrsg), Parrhesia, Karl Barth zum achtzigsten Geburtstag, 149172. Zürich: EVZ.

Scholz, H 1931. Wie ist eine Evangelische Theologie als Wissenschaft möglich? Zwischen den Zeiten 1, 8-53.

Schwöbel, C 2000. Theology, in Webster 2000b:17-36

Torrance, T F 1962. Karl Barth: An introduction to his early Theology, 1910-1931. London: SCM.

Torrance, T 1990. Karl Barth, Biblical and evangelical theologian. Edinburgh: T\&T Clark.

Pannenberg, W 1967. Heilsgeschehen und Geschichte, in Grundfragen Systematischer Theologie. Gesammelte Aufsätge, 22-78. Göttingen: Vandenhoeck \& Ruprecht.

Van Huyssteen, W 1989. Theology and the justification of faith. Michigan, MI: Eerdmans.

Von Balthasar, H U 1951. Karl Barth: Darstellung und Deutung seiner Theologie. Cologne: Hegner.

Veldsman, D P 1996. Die stil van my verlange na God: Oor Johann Wilhelm Herrmann se verstaan van die ervaring van God (Deel I). Skrif en Kerk 17(2), 456-472.

Veldsman, D P 1997. Die stil van my verlange na God: Oor Johann Wilhelm Herrmann se verstaan van die ervaring van God (Deel II). Skrif en Kerk 18(1), 198-209.

Webster, J 2000a. Barth. London: Continuum.

Webster, J (ed) 2000b. The Cambridge Companion to Karl Barth. Cambridge: Cambridge University Press. 